Madrygal. Revista de Estudios Gallegos

ISSN: 1138-9664

\title{
Desde la añoranza. Recordando a Mariví Villaverde
}

Carmen Mejía Ruiz ${ }^{1}$

El día 23 de abril de 2017 nos dejó María Victoria Villaverde de Valenzuela (Villagarcía 1922 - Adina, Pontevedra 2017). Escritora exiliada, estuvo muy vinculada a la Federación de las Sociedades Gallegas de Buenos Aires junto a Ramón de Valenzuela, su marido. Se relacionó con la intelectualidad gallega del momento, manteniendo una amistad muy estrecha con Eduardo Blanco-Amor, Arturo Cuadrado y Luís Seoane, entre otros. Este último será quien, en 1962, le publique en la Editorial Alborada Tres tiempos y la Esperanza, la novela que Mariví Villaverde escribió "para que quedara", para dejar testimonio de los tiempos de la República, de la llegada de la Guerra Civil y del exilio. Arturo Cuadrado en el prólogo de esta edición afirma:

No es nada fácil alcanzar ese estado de gracia que es el asombro. Para ello es preciso que una joya nos deslumbre, un árbol florezca o una tormenta nos ciegue o nos enloquezca. Todo esto nos arrebata ante Tres tiempos y la Esperanza. Una ola violenta sobre el mundo arrastrando a hombres y pueblos para someter hasta el propio paisaje en la locura. Y sobre grises y sombras el florecimiento de la esperanza. (p. 7)

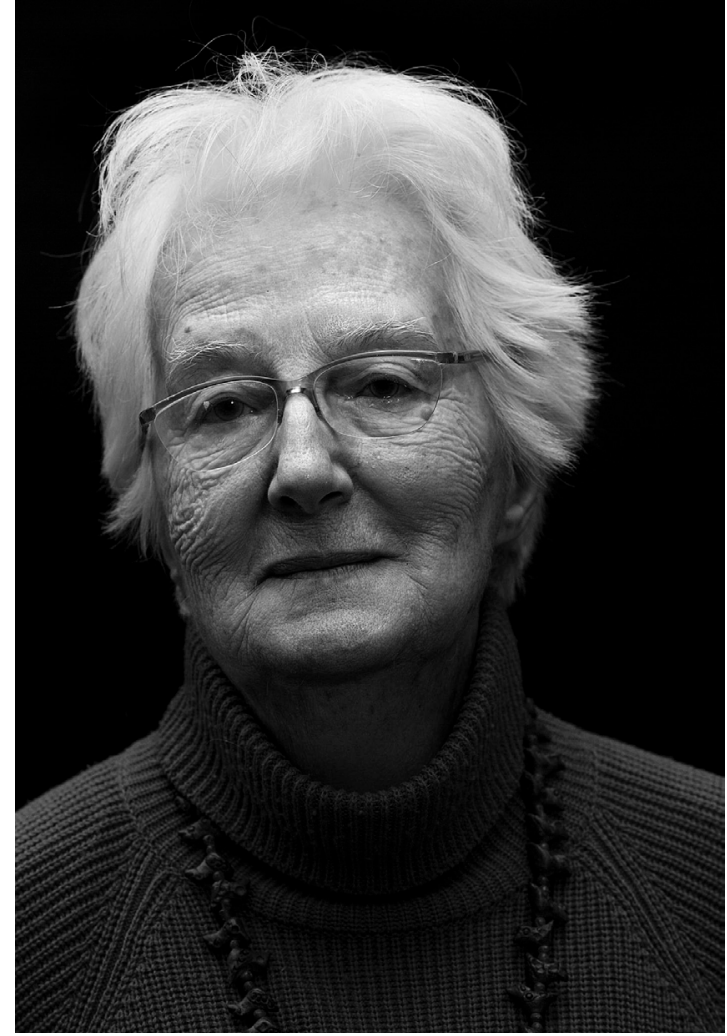

Foto: Xurxo Lobato (Rostros da memoria)

Universidad Complutense de Madrid, Departamento de Filología Románica, Filología Eslava y Lingüística General.

E-mail: cmejiaru@ucm.es 
Por su parte María Teresa León escribe en la revista Galicia de Buenos Aires en agosto de 1962 una reseña:

Comienza el libro de María Victoria Valenzuela: «Aquella era una casa grande»... Sí, aquella era nuestra casa grande y alta. Se llamaba España. Cada uno de nosotros la individualizaba con un nombre: Cataluña, Castilla, Galicia (...) Tres tiempos y la Esperanza ha tenido la virtud de hacernos abrir de nuevo la ventana del pasado donde podemos inclinarnos para soñar con el futuro. (p. 12)

Un futuro en el que Mariví Villaverde tenía puestas muchas esperanzas, pero la fundamental era la de alcanzar las Libertades que, en su día, llegaron y que se llevó con ella. Una mujer llena de vida, que tenía a Galicia siempre en el corazón y a la que tanto añoramos. 